\title{
FEATURE Managing manure for sustainable livestock production in the Chesapeake Bay Watershed
}

Peter Kleinman, Kristen Saacke Blunk, Ray Bryant, Lou Saporito, Doug Beegle, Karl Czymmek, Quirine Ketterings, Tom Sims, Jim Shortle, Josh McGrath, Frank Coale, Mark Dubin, Daniel Dostie, Rory Maguire, Robb Meinen, Arthur Allen, Kelly O’Neill, Lamonte Garber, Mark Davis, Bobby Clark, Kevin Sellner, and Matt Smith

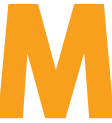

anure presents one of the greatest challenges to livestock (dairy and beef cattle, swine, poultry, equine, sheep, llamas, etc.) operations in the Chesapeake Bay Watershed, serving both as resource and liability. The Chesapeake Bay is threatened by excessive nutrient loadings, and, according to the US Environmental Protection Agency (USEPA),

Peter Kleinman, Ray Bryant, and Lou Saporito are soil scientists at the Pasture Systems and Watershed Management Research Unit, USDA Agricultural Research Service, University Park, Pennsylvania. Kristen Saacke Blunk is director of the Agriculture and Environment Center, Penn State University, University Park, Pennsylvania. Doug Beegle is distinguished professor at the Department of Crop and Soil Sciences, Penn State University, University Park, Pennsylvania. Karl Czymmek is senior extension associate and Quirine Ketterings is associate professor at the Department of Animal Science, Cornell University, Ithaca, New York. Tom Sims is deputy dean at the College of Agriculture and Natural Resources, University of Delaware, Newark, Delaware. Jim Shortle is distinguished professor at the Department of Agricultural Economics and Rural Sociology, Penn State University, University Park, Pennsylvania. Josh McGrath is assistant professor, Frank Coale is professor, and Mark Dubin is agricultural technical coordinator at the Department of Environmental Science and Technology, University of Maryland, College Park, Maryland. Daniel Dostie is state resource conservationist at the USDA Natural Resources Conservation Service, Harrisburg, Pennsylvania. Rory Maguire is associate professor at the Department of Crop and Soil Environmental Sciences, Virginia Tech University, Blacksburg, Virginia. Robb Meinen is senior extension associate at the Department of Dairy and Animal Science, Penn State University, University Park, Pennsylvania. Arthur Allen is professor at the Department of Agriculture, University of Maryland Eastern Shore, Princess Anne, Maryland. Kelly O'Neill is agricultural policy analyst and Lamonte Garber is agricultural program manager at the Chesapeake Bay Foundation, Harrisburg, Pennsylvania. Mark Davis is executive assistant to the secretary at the Delaware Department of Agriculture, Dover, Delaware. Bobby Clark is senior extension agent, Agricultural and Natural Resources, Virginia Cooperative Extension, Woodstock, Virginia. Kevin Sellner is director of Chesapeake Research Consortium, Edgewater, Maryland. Matt Smith is national program leader, Agriculture and Industrial Byproducts Program, USDA Agricultural Research Service, Beltsville, Maryland. manure is the source of $18 \%$ of the nitrogen and $27 \%$ of the phosphorus entering the Chesapeake Bay annually (figure 1) (Chesapeake Bay Program 2010). Developing economical, practical, and effective manure management options for livestock producers will not only contribute to the restoration of the Chesapeake Bay, but will also provide a model for other areas where water quality and livestock production objectives must be balanced.

The 166,000 $\mathrm{km}^{2} \quad\left(64,000 \mathrm{mi}^{2}\right)$ Chesapeake Bay Watershed is home to 3.2 million animal units (animal unit $=$ $454 \mathrm{~kg}$ [1,000 lbs] of livestock) generating roughly 36 million $\mathrm{t}$ (40 million $\mathrm{tn}$ ) of livestock manure per year. In comparison, the 14 million humans who call the Chesapeake Bay Watershed home generate 3.6 million $\mathrm{t}$ ( 4 million $\mathrm{tn}$ ) of waste annually (Brosch 2010; Blankenship 2005). The livestock manure contains approximately $259,000 \mathrm{t}(285,000 \mathrm{tn})$ of nitrogen and 70,000 t (77,000 tn) of phosphorus.
Most manure is applied near the livestock housing on less than $10 \%$ of the 47,000 $\mathrm{km}^{2}\left(18,000 \mathrm{mi}^{2}\right)$ of the watershed's agricultural land (row crop and grassland). High concentrations of livestock in the Delmarva Peninsula (Delaware, Maryland, Virginia), Shenandoah Valley of Virginia, and Lancaster County region of Pennsylvania have created regional manure nutrient hotspots (Chesapeake Bay Program 2010). These hotspots result from farming systems that rely heavily on imported feeds (hence nutrients). Many of these imported nutrients do not leave the farm in the form of animal products.

Manure represents the inherent inefficiency of animals in metabolizing feed resources. Ideally, this byproduct should be managed as a resource (e.g., soil amendment, feedstock for energy production, source of livestock bedding). It is well established that manure provides fertility and tilth benefits to soils (Piccinini and Bortone 1991) and that its carbon

\section{Figure 1}

Annual production of manure nutrients (lbs) in 2009 in counties of the Chesapeake Bay Watershed. (a) Manure nitrogen. (b) Manure phosphorus. Location of the watershed is identified in the inset map of the United States. Adapted from Brosch (2010).

(a)

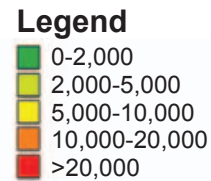

(b)

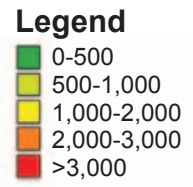

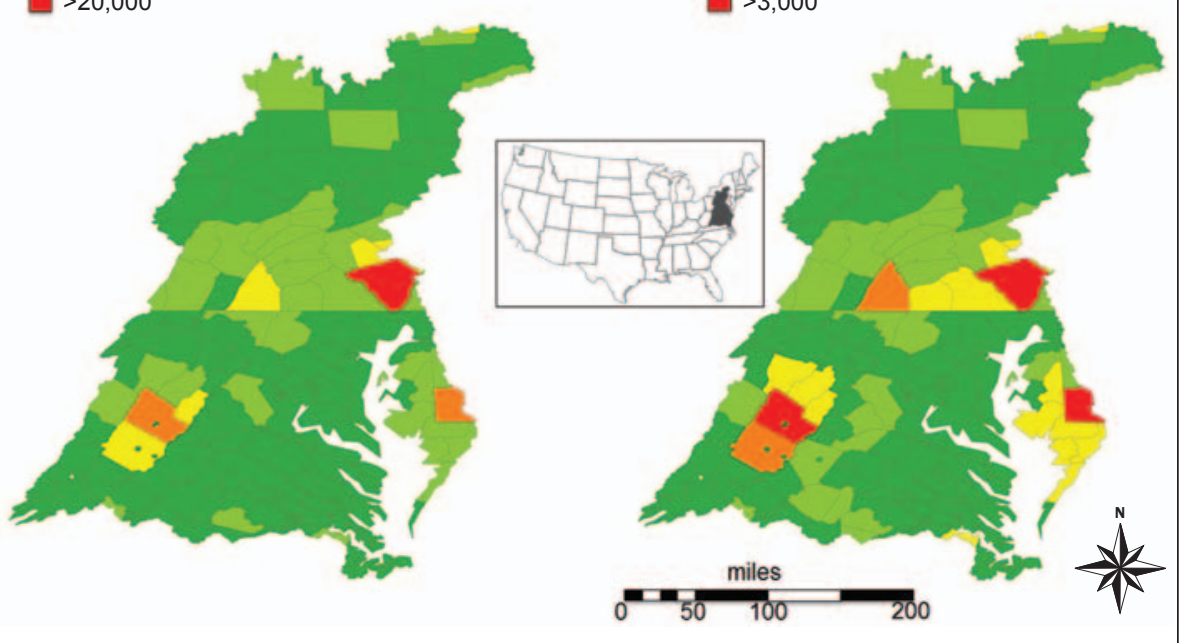


can be converted into energy by digestion and pyrolysis (Tafdrup 1995; Lima et al. 2009). However, given its bulky nature, odor, potential pathogens, low nutrient concentration, imbalance of nutrients relative to crop requirement, and regulatory paperwork requirements, manure quickly becomes a liability to those who manage it. The marketplace has sought to provide trade options, both free and for environmental credit, but demand at the local level, combined with limitations in manure availability, storage, handling, transport costs, and value, overwhelm building a stable market for manure and its byproducts (Ribaudo et al. 2003). There continues to be substantial use of commercial fertilizer in the watershed $(370,000 \mathrm{t}$ [408,000 tn] of nitrogen and $47,000 \mathrm{t}[52,000 \mathrm{tn}]$ of phosphorus) that could be replaced by more efficient use of manure nutrients. Even when strong demand exists, off-site transfer of manure can be hampered by logistical obstacles. As such, it is generally the rule that manure's greatest net value lies at or near the source where it is generated. Because manure has a low nitrogen-to-phosphorus ratio, applying manure to meet crop nitrogen needs overapplies phosphorus, and with repeated manure applications, soil phosphorus accumulates well above crop needs, causing environmental concern. With overapplication, the value of manure (organic matter, phosphorus, potassium, and micronutrients) diminishes and only the nitrogen remains as an economic benefit to farmers.

President Obama's 2009 Executive Order 13508 placed the Chesapeake Bay at the highest level of federal concern, and the 2010 promulgation of a "Bay Diet" under the Clean Water Act (USEPA's Total Maximum Daily Load [TMDL]) introduced both resources and urgency to the quest to significantly advance manure management in the Chesapeake Bay Watershed (Stubbs 2011; Federal Leadership Committee for the Chesapeake Bay 2010). The challenges are many fold-the most recalcitrant rooted in the structure of our food production systems requiring profound systemic changes and the most achievable involving expanded adoption of management prac- tices that improve both water quality and crop or forage production.

\section{INDUSTRY-SPECIFIC MANURE MANAGEMENT ISSUES}

Poultry. Poultry production is spatially concentrated in the Delmarva Peninsula, Lancaster County region, and Shenandoah Valley, primarily due to vertical integration and economics. Vertical integration means that a poultry company owns a feed mill and processing plant and contracts with local farmers to grow their birds with their feed. Transport costs make it economical to raise the birds close to the source of feed and the processing plant. Across the watershed, chickens and turkeys generate $24 \%$ of the total livestock manure wet weight, containing $49 \%$ of the phosphorus and $44 \%$ of the nitrogen found in all livestock manures (Brosch 2010). Traditionally, meat poultry generated dry litter $(<30 \%$ moisture), whereas egg layers (i.e., battery cage operations) produced semi-solid manure (40\% to $60 \%$ moisture). However, a growing number of modern egg facilities now employ drying belts that yield powder-dry manure. Long-term trends in feed use efficiency (rations and genetic selection) have resulted in $>80 \%$ reduction in nitrogen and phosphorus excretion by broilers since the 1950s. In addition, over the past decade, the widespread, voluntary use of phytase, combined with lower addition of phosphorus to poultry diets, has further lowered litter phosphorus content. However, poultry litters possess high nutrient concentrations compared with cattle and swine manures.

This relatively high nutrient density and predominance of dry manure production result in considerably lower transport costs for poultry litter compared to liquid manures, causing poultry manure to have the greatest potential for export and value-added processing. Because poultry litter is a preferred soil fertility and liming amendment for many producers, there has been significant industry and government investment in manure export activities. Perdue's AgriRecyle plant (Seaford, Delaware) was constructed to pelletize approximately $14 \%$ of the litter generated on the Delmarva Peninsula and supplies pelletized litter to a large segment of the organic fertilizer amendment industry. In addition, a growing number of innovative technologies have been developed to provide poultry farmers with opportunities to gain value from the export of their litter (cofiring, gasification, baling).

Cattle. Cattle operations are largely found in the upland reaches of the Chesapeake Bay Watershed. Modern dairy farms produce much of their own feed, with crops such as corn silage and alfalfa. However, they also import large quantities of feed concentrates, and much of the nutrients in these end up in manure. Dairy operations within the region tend to be small $\left(<100\right.$ head farm $\left.^{-1}\right)$, organized in diffuse cooperatives of independent producers, accounting for $26 \%$ of all animal units, $20 \%$ of manure phosphorus, and $24 \%$ of manure nitrogen in the watershed (Brosch 2010). With the notable exception of the Lancaster region of Pennsylvania, the land base of most dairy operations is extensive ( $>57$ ha farm $\left.{ }^{-1}\left[140 \mathrm{ac} \mathrm{farm}^{-1}\right]\right)$. Even so, considerable opportunity exists for precision feeding to reduce nutrients in manure. Manure storage, once uncommon, is increasingly found on dairy farms and is ubiquitous on large operations. However, a 2001 survey of small dairy farms in southcentral Pennsylvania reported that 19\% had no storage capacity (Dou et al. 2001). The liquid nature of most stored dairy manure reduces its potential for transport to any significant distance.

Beef operations in the region are largely pasture based and small in size. Beef cattle produce $12 \%$ of the manure in the watershed $(10 \%$ of total manure phosphorus and $10 \%$ of total manure nitrogen), most of which is directly deposited onto pastures as dung or accumulated at holding areas as semisolid pack (Brosch 2010). As these beef operations are pasture based and do not rely heavily on imported feed, they do not generate excess manure nutrients typical of more intensive confined animal feeding operations.

Given the volume and variable quality of cattle manure generated in the watershed, as well as the diffuse structure of the industry, moving cattle manure off-farm is a major challenge. Dairy operations have engaged in a variety of manure-processing practices, including liquid/solid separation 
that enables the operator to land apply liquids, smaller particles, and their dissolved constituents and recycle the solids as bedding or compost. Some large dairy operations have installed anaerobic digesters to offset onfarm energy costs and tackle manure odor concerns, but these systems do not alter on-farm nutrient balances, require significant public investment, increase manure nutrient solubility, and do not inherently lead to off-farm manure export.

Swine. The swine industry in the Chesapeake Bay Watershed accounts for only $5 \%$ of the total animal units, $6 \%$ of the manure phosphorus, and 5\% of the manure nitrogen (Brosch 2010). Like poultry, most swine are produced in vertically integrated operations, creating opportunities for uniform programmatic coordination. Also like poultry, swine have benefited from the combination of phytase addition and lower phosphorous concentrations in feed to improve metabolism, decreasing excretion of phosphorus. Unlike poultry, the manure generated by swine is primarily stored in pits, tanks, or lagoons in liquid form ( $<5 \%$ solids). The liquid nature of swine manure and bad odor compared with other manures pose substantial barriers to off-site manure hauling for land application. However, due to its low solids content, liquid swine manure is readily injected and quickly infiltrates into well-drained soils when land applied, making it easier to incorporate into soil than dairy and poultry manures. Some larger swine operations are also experimenting with anaerobic digesters.

PLAIN SECT AND LIFESTYLE FARMS The growing human population in rural areas of the Chesapeake Bay Watershed has been accompanied by an expansion of plain sect farms (i.e., Amish, Mennonite, German Baptist), as well as lifestyle (hobby) farms. These mostly smaller but highdensity operations may have a larger, albeit unmeasured, aggregate impact. Indeed, horses account for $11 \%$ of the animal units in the watershed, gener- ating $8 \%$ of the weight of fresh manure (Brosch 2010). Extension and outreach programs have increasingly focused on these farms to promote practices that have been successfully implemented on larger operations. There is a particular need to address poor barnyard infrastructure, pasture management (e.g., stream bank fencing, riparian buffers, alternative watering systems, improved stream crossings, pasture harrowing, rotational grazing), and even manure export (e.g., strong demand exists for horse manure by the mushroom growers).

\section{CROP FARMS}

The potential to balance manure nutrients within the Chesapeake Bay Watershed rests in the $>90 \%$ of farmland that is not managed by livestock operators. Considerable demand exists to transfer manure generated from livestock operations to crop farms within the watershed's boundaries. However, major barriers, especially the high transportation costs, persist, impeding the ready flow of manure from areas of nutrient excess to deficit areas. Off-farm barriers include community relations, uncertainty in costs, convenience (commercial fertilizer nutrient concentration is much higher than manure and more readily available), differential annual needs of crops in relationship to manure nutri- ent ratios, complexity in permitting (real and perceived), adolescent infrastructure and brokering systems to transfer manure, limited agility in tailoring supportive conservation programs, and unsynchronized timing between manure availability and agronomic demand. Even in areas with relatively well-established manure export systems (e.g., Delmarva Peninsula's poultry production region), crop farms have difficulty gaining access to local manure sources, particularly when fertilizer prices are high due to deep discounting of manure nutrient value as compared with commercial fertilizers. Indeed, there has been little integration of the commercial fertilizer industry (which often generates nutrient management recommendations for farmers) with agencies and programs implementing manure management planning, resulting in missed opportunities to substitute manure nutrients for commercial fertilizer nutrients.

\section{PRIORITY MANURE MANAGEMENT} CHALLENGES AND ACTIONS

Achieving Nutrient Balance. The single greatest challenge facing livestock operators in the Chesapeake Bay Watershed remains the accumulation of nutrients, especially phosphorus, on farms. This imbalance derives from flows of nutrients from major grain-producing regions in the

\section{Figure 2}

General estimated flows of nitrogen and phosphorus related to livestock production in the Chesapeake Bay Watershed.

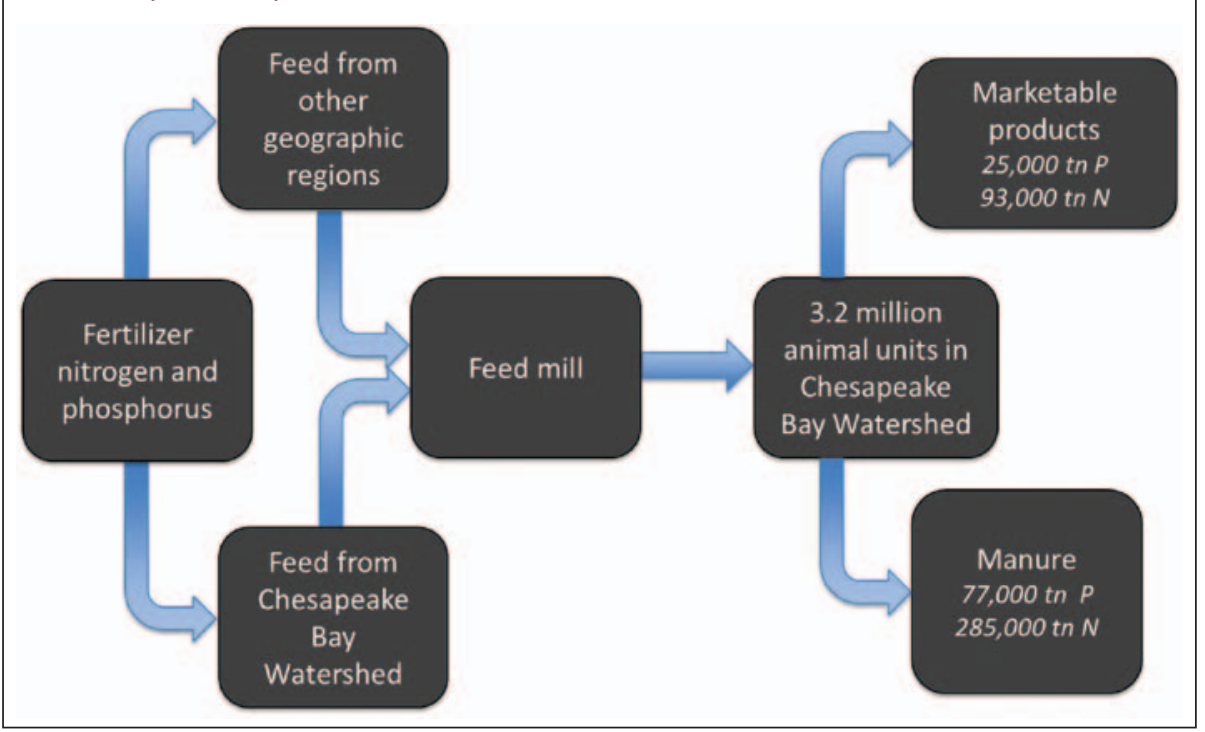


Midwestern United States to livestockproducing regions such as the Chesapeake Bay Watershed (figure 2). Strong market forces drive the nutrient flows, reinforced by commodity programs that favor specialization and intensification. Without a nutrient balance at farm, subwatershed, and Chesapeake Bay Watershed levels, manure nutrients will eventually overwhelm the assimilative capacity of the local environment.

On the farm, ensuring implementation of sound field-based nutrient management plans can improve manure nutrient distribution and nutrient use efficiency; however, nutrient management planning at the field level cannot solve the problem of nutrient imbalances that exists at the farm. The whole farm system needs to be considered comprehensively and optimized (e.g., herd nutrition and management, storage of feed, storage of manure). Larger management scales and markets must be engaged.

On-farm technologies that add value to manure and encourage export, including composting, solid-separation, and anaerobic digestion, while increasingly emphasized, are insufficient on their own to drive manure export at a large scale. Practices such as digestion and pyrolysis return energy and provide other nominal benefits; however, they either retain the very nutrients that are the source of the imbalance or drive off the nitrogen fraction, worsening the nitrogen-to-phosphorus ratio relative to crop requirement. Too often these practices are viewed as a solution, but have not been tied to the offfarm manure export necessary for success.

Dry manure (and litter) generated by poultry and horse farms has the greatest potential for export as it can be shipped "as-is," baled to enable storage, or pelletized to improve its commercial potential as organic fertilizer. Demand exists for dry manures, but market prices may not fully compensate livestock operators for the fertilizer value of the manure they export. Even for the smallest farms, engagement with available programs must be made possible through trialing of creative projects such as provision of manure storage dumpsters to stables, recruiting commercial manure haulers to aggregate diffuse manure sources, and tying these distribution networks to users like the mushroom and landscape industries.

The Chesapeake Bay Watershed will undoubtedly serve as a proving ground for projects aimed at moving manure and other byproducts (e.g., municipal biosolids, food wastes) from areas of excess to deficit areas. To promote efficient, sustainable use, these projects should emphasize managing the cycling of nutrients within the watershed to minimize nutrient losses in balance with export outside of it. For instance, energy-derived returns from onfarm anaerobic digesters should be used to promote the export of surplus manure nutrient by-products. This is best achieved by tapping private sector resources and innovation. For example, the fertilizer industry should be involved in manure transfer activities to address the fertilizer replacement needs created by mass reallocation of manure nutrients and leveraging private sector innovation related to marketing and distribution networks. Regional "enhanced" manure treatment systems, such as Pennsylvania's Cove Area Regional Digester, slated to treat manure for 25,000 cows, are features of state and federal technology-based approaches for watershed improvements. These projects would reduce producers costs for managing manure (>US\$300 $\mathrm{cow}^{-1} \mathrm{yr}^{-1}$ ), export manure solids from the area, and treat effluent to water quality standards. While regional treatment systems hold clear potential in intensive livestock production areas, existing projects are struggling to build viable business plans that ensure economic sustainability, even with approval by nutrient credit trading programs.

The most difficult manure-management problems derive from the regional structure of our livestock productions systems. Structural adjustments are needed to more efficiently cycle nutrients at regional scales, tie manure nutrient production and fertilizer use to local nutrient cycles, and internalize the complete costs (production and environmental) of manure management. Decisions of who will bear these costs will require national dialogue.

The success of manure export from the farm to balance nutrients at broader scales lies in the development of coherent, complete markets that overcome the deficiencies of manure as a fertilizer source. Although manure brokering or relocation programs have been established by major livestock-producing states to facilitate off-farm transfer (e.g., Pennsylvania, Maryland, Virginia), they are underutilized and adolescent in form and scope. Effort must be made to build demand for manure where there is nutrient deficit (minimizing paperwork barriers, making manures competitive with commercial fertilizers, improving marketing) and to facilitate logistics (ensuring that quality manure is available when and where there is demand).

Developing Markets to Sustain Manure Management Practices and Systems. Change in manure management within the Chesapeake Bay Watershed has largely been driven by regulatory and governmental assistance programs. Payment for ecosystem services has allowed federal and state dollars to support farm-based conservation that aims to reduce the potential emissions of nutrients. Best management practices (BMPs) for manure management have long been cost-shared by producers, USDA Natural Resources Conservation Service (NRCS), state agencies, conservation or soil and water districts, and others. However, building reliable markets for sustaining and improving manure management, particularly as cost-sharing programs diminish, are critical to institutionalize improved manure management alternatives in the watershed.

Bay-based nutrient trading programs, such as those established in Pennsylvania, Virginia, Maryland, and West Virginia, do offer early evidence that credits (or nitrogen and phosphorus reductions) generated by farms can be sold to National Pollutant Discharge Elimination System permit holders (wastewater treatment plants) to meet permit discharge requirements (Parker 2004). These programs require farms to meet baseline standards and to perform above the baseline to generate tradable credits. Experiences in the United States and internationally suggest that investments in the development of markets and utilization of traditional agricultural conservation agency programs are critical to market success (Shortle 2011). 
There is an expectation that the establishment of the bay-wide TMDL can provide a quasi-regulatory driver for fostering nutrient trading by imposing a cap on the regulated discharge of pollutants, creating a buyer for credits generated by the agricultural producers. Whether nutrient credit trading can parallel and potentially offset current levels of annual public funding for agriculture conservation co-share programs for the bay is unknown, but of high interest.

A not yet developed but promising innovation for manure management in the region are manure markets that incentivize redistribution of manure from surplus to deficit areas. The geographic scope of markets is limited by the economic value of manure to recipients relative to the cost of hauling. The economics have improved with higher fertilizer prices and more stringent nutrient regulations (i.e., regulations that restrict application of manure nutrients). Manure exchange programs seek to match manure suppliers (livestock operations with inadequate acreage for spreading) with entities seeking organic materials for field application or other uses. While the scale of such exchanges is nominal, there is growing interest in both the landscape and urban gardening arenas for building win-win trading scenarios in which the nutrient rich materials from animal operations are utilized in areas that would otherwise be limited to commercial fertilizers. Municipal biosolids programs that employ producers in the use and management of wastewater treatment plant byproducts are evidence that larger-scale contractual manure trading is economically and technically possible.

Improving Compliance with Manure, Erosion, and Sediment Control Rules. Environmental compliance in the Chesapeake Bay Watershed has been varied, particularly for smaller farms that are perceived to fall below regulatory thresholds or for which regulators have been less likely to pursue compliance. Every state in the watershed has manure or conservation requirements for all farms (table 1) and are seeking to improve communication of their rules and guidelines in response to TMDL mandates, albeit, a perception per- sist that these rules are new, abrupt, overly stringent, and even unrealistic.

Improving compliance is a complex task that includes leveraging limited resources, balancing different programmatic emphases, and requiring prioritization that considers not just environmental benefit but also the ability of farms to make meaningful management adjustments. Adaptive management has emerged as a philosophy for engaging, educating, and affecting long-term change on farms, small to large. This requires a willingness to support onfarm practices and strategies that constitute effective change and can be counter to the enforcement of regulatory paperwork that the agencies are required to fulfill. Several adaptive management pilot programs are underway in the Chesapeake Bay Watershed (e.g., Pennsylvania's Conewago Creek Initiative), showing success in recruiting and maintaining participants.

The challenges to enforcing compliance are largely economic, as many changes in on-farm manure management will incur costs. Dwindling state and county resources have eroded the very programs needed to buffer on-farm transitions. The task of improving compliance must be grounded in education of manure managers and community support networks, which necessitates maintenance of available resources to do so. Compliance discussions must include realistic assessments of all alternatives, beyond just achieving compliance with adoption of required BMPs.

Improving On-Farm Infrastructure. On-farm infrastructure in the Chesapeake Bay Watershed often dates back many decades, particularly on small farms where resources are most limited. Today, unimproved barnyards and areas of heavy animal use represent major sources of manure nutrient loss, especially when located in proximity to water bodies. Manure storage facilities are often absent or inadequate. In part, these deficiencies may be attributed to the limited financial and technical assistance available for infrastructure improvements, as well as to the enormity of the cost. Prudent investment in manure infrastructure demands flexible, farm-specific solutions that weigh the various requirements of particular solu- tions (e.g., installation of manure storages require ability to handle and apply manure in a timely fashion) with objective expectations of return on investment (even well-constructed barnyards and manure holding areas can be undermined by flooding when they are installed on farmsteads that are located along waterways)

Precedent exists for promoting infrastructure innovation to improve cost effectiveness. The New York City Watershed Agriculture Program, responsible for major water-quality improvements in New York's drinking water supply, provided cost support for practices that improved drinking water reservoirs and pioneered new practices, such as covered barnyards and solar calf housing that were not recognized as approved standard practices at the time. Excellent examples of innovation on unpaved heavy use areas can be found within the Chesapeake Bay Watershed, including rotational lot management systems that emphasize moving animals away from hydrologically active areas, prudent selection of heavy use areas, and maintenance of vegetation through rotation. Continued experimentation, outcome-oriented design standards, and official encouragement of innovation are needed to ensure the broadest array of options for the diverse farming conditions of the watershed.

Given the pressing cost to develop or retrofit infrastructure, it is critical to prioritize investment, as well as to promote creative, cost-effective alternatives. Better decision-support tools are needed to prioritize infrastructure investments, particularly cost/benefit comparisons with other manure management investment opportunities. Experience reveals that rigid approaches to infrastructure-related problems rapidly become cost-prohibitive and can be confounded by site-specific factors. Instead, trained field personnel offer the most effective means of weighing site specific options, linking infrastructure needs with funding sources, and prioritizing and coordinating actions across multiple operations.

Advancing Land Application PracticesMinimum Disturbance Incorporation. With more than two-thirds of the agricultural land in the watershed in no-till 


\section{Table 1}

Manure management priorities identified by states in their respective Watershed Implementation Plans for meeting the Chesapeake Bay Total Maximum Daily Loads.

\begin{tabular}{|c|c|}
\hline Bay state & anure management priorities identified in state watershed implementation plans \\
\hline Delaware & $\begin{array}{l}\text { - All nutrient handlers must implement state-approved phosphorous-limiting nutrient management plans. } \\
\text { - Winter manure application is prohibited. } \\
\text { - Phosphorus is managed based on the P Index. } \\
\text { - All CAFOs are required to implement a nutrient management plan as part of their NPDES permit. } \\
\text { - A state program exists to relocate manure to farms that need the nutrients or for alternative uses. } \\
\text { - The state invests in no-till, cover crops, precision agriculture, and heavy use area protection. }\end{array}$ \\
\hline Maryland & $\begin{array}{l}\text { - Nutrient management plans require farms to efficiently use manure or fertilizer needed to grow a healthy } \\
\text { crop and ensure that excess nutrients are not lost to the environment. } \\
\text { - Phosphorus is managed based on the P Index. } \\
\text { - CAFOs are required to have } 100 \mathrm{ft} \text { setbacks from riparian areas for manure application. A } 10 \mathrm{ft} \text { setback is required for all non-CAFOs } \\
\text { - State emphasis is on manure and poultry litter injection, livestock and poultry waste facilities, and manure treatment and transport. }\end{array}$ \\
\hline New York & $\begin{array}{l}\text { - CAFOs are required to implement a comprehensive nutrient management plan as part of their NPDES permit. } \\
\text { - Agricultural Environmental Management Program supports farm efforts to protect water quality and conserve natural resources } \\
\text { through voluntary incentives to adopt BMPs. } \\
\text { - Agricultural Nonpoint Source Abatement and Control Program provides competitive financial assistance to implement BMPs, } \\
\text { including conservation and no-tillage, cover crops, enhanced nutrient management, stream protection, pasture management, } \\
\text { barnyard runoff controls, and animal waste management systems. }\end{array}$ \\
\hline Pennsylvania & $\begin{array}{l}\text { - CAFOs are required to implement a nutrient management plan as part of their NPDES permit. } \\
\text { - Livestock operations with > } 2 \text { animal equivalent units per acre must develop and implement a nitrogen- and phosphorus-based } \\
\text { - An updated Manure Management Manual requires manure management plans on all farms that generate or utilize manure. } \\
\text { Plans include application rate restrictions and automatic setbacks from water bodies on farms without higher level plans in place. } \\
\text { - Agricultural Erosion and Sedimentation Plan is required of all farms that plow or till (including no-till for more than } 5,000 \mathrm{ft}^{2} \text { ). } \\
\text { - State emphasis is on the development of new technologies to address excess nutrients and market-based programs to facilitate } \\
\text { adoption of BMPs to reduce the impact of nutrients on the environment. }\end{array}$ \\
\hline Virginia & $\begin{array}{l}\text { - Resource management plans are required on most acres. State emphasizes improved tracking of voluntary nutrient } \\
\text { management BMPs. } \\
\text { - CAFOs must implement a nutrient management plan as part of their NPDES permit. } \\
\text { - All poultry litter applied to farmland must meet minimum nutrient management standards established by the Virginia Department } \\
\text { of Environmental Quality. } \\
\text { - Permits are required for certain poultry operations that are not classified as CAFOs. } \\
\text { - State provides cost-share funding to achieve implementation of incentive-based practices. }\end{array}$ \\
\hline West Virginia & $\begin{array}{l}\text { - CAFOs are required to implement a nutrient management plan as part of their NPDES permit. } \\
\text { - State focus is on having voluntary plans for all of agriculture. } \\
\text { - Transfer of one-third of the poultry litter out of the Chesapeake Bay Watershed is targeted. } \\
\text { - Emphasis is on targeting the two counties with the highest nitrogen delivery factor for increasing the number of acres under a } \\
\text { nutrient management plan. }\end{array}$ \\
\hline
\end{tabular}

Notes: BMP = best management practice. CAFO = Concentrated Animal Feeding Operation. NPDES = National Pollutant Discharge and

Elimination System.

or perennial cover (hay, pasture), nearly all manure is applied to the soil surface. No-till reduces erosion, but it leaves applied manure on the surface where it is vulnerable to runoff and atmospheric emission. Incorporation of manure into soil by conventional tillage has not been advocated because of erosion concerns, even though phosphorus management guidelines of Chesapeake Bay states recommend immediate incorporation following application to soils of low erosion potential. Expanding the options to directly incorporate manure into soil with the least disturbance is critical to improving soil health and productivity, improving nutrient use efficiency by crops, and minimizing impacts to air and water quality.

Adoption of manure injection technologies in the Chesapeake Bay Watershed is scant, due in part to the difficulty in using 
traditional, deep injection techniques on the steep, stony soils that characterize the uplands of the watershed and also the limited experience of farmers with injection technologies. Following considerable testing by government and land-grant institutions, new technologies, such as shallow manure injection, aerator-linked applicators, and subsurface litter applicators, show promise for most of the farming systems of the region (figure 3). Growing recognition for their potential includes bay-focused USDA NRCS incentives for farmers to inject manure and their explicit recognition by states and USEPA as "next generation nutrient management practices” (USEPA 2010; USDA NRCS 2011). Greater adoption of minimum-disturbance manure application technologies requires investment in economical technology transfer activities, including (1) demonstration and technology-transfer activities, (2) peer-based communication of value (farmer-to-farmer), and (3) private sector support.

Manure Processing and Treatment. Opportunities exist to process or treat manure for economic, agronomic, and environmental enhancement. However, a large number of treatments have been marketed for manures with little to no scientific basis to their purported benefits (e.g., odor control, improved nutrient bioavailability). For those manure processing or treatment practices that are underpinned by science, the benefits include conserving or stabilizing nutrients to improve manure nutrient use efficiency, reducing bulk, pathogens, and odors to make manure more competitive with commercial fertilizers, and deriving additional value from manure to support export and/or improve other aspects of manure management. Well-established practices include solid-separation, which may be used to generate bedding or litter, chemical treatment, which is generally underutilized but can stabilize and conserve nutrients, and composting, vermicomposting or pelletizing to generate marketable products.

Stronger emphasis is needed in combining processing and treatment practices to conserve manure nitrogen from barn to field. Processes such as composting and pyrolysis significantly lower the nitrogen

\section{Figure 3}

The USDA Agricultural Research Service "Subsurfer," a novel technology that incorporates dry poultry litter into soils with minimum disturbance.

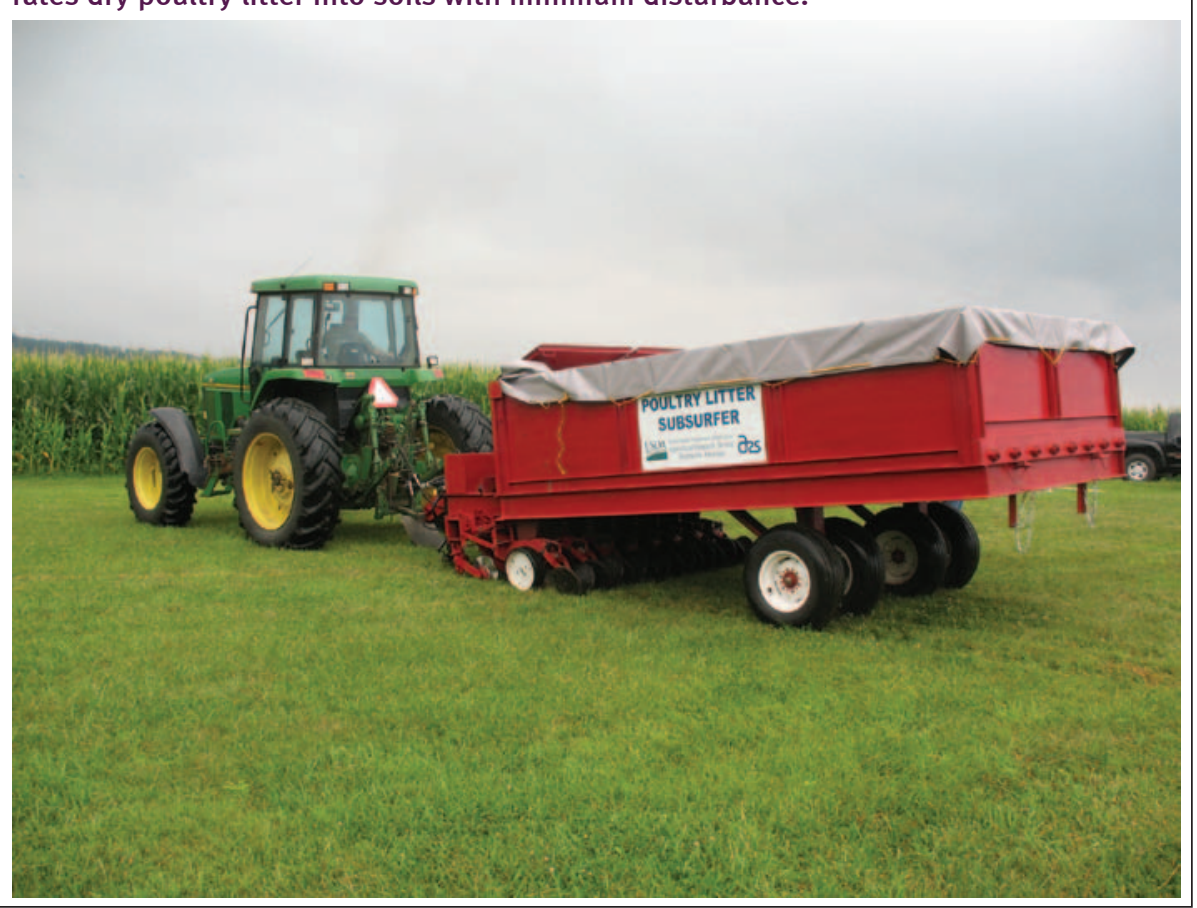

content of the final product (compost, biochar). Chemical amendments such as alum (aluminum sulfate) and ferric chloride lower ammonia volatilization and stabilize phosphorus so that it is less susceptible to runoff when manure or its byproducts are land applied. Notably, anaerobic digestion and solid separation processes render nutrients in the liquid fraction more susceptible to chemical treatments that can improve the nitrogen-to-phosphorus ratio. In addition, separation of manure into homogenous liquid and solid $(<30 \%$ moisture) fractions improves its properties for injection or subsurface placement.

A variety of manure processing technologies exist that offer energy, fuel, or other economic returns to farmers. These range from anaerobic digesters (on-farm, regional, enhanced) to pyrolysis units to on-farm nutrient-recovery systems (e.g., USDA's Super Soil Saver). These cannot be viewed as stand-alone practices; rather, they must be integrated into systems of manure management that move manure nutrients to areas where production demand and environmental concerns are balanced. A frequent limiting factor is that these systems are often capital and management intensive. Therefore, they must be weighed as part of the infrastructure investment process so that the costs and benefits are understood in comparison with alternatives.

\section{ACKNOWLEDGEMENTS}

This white paper is constructed from the collective input of participants in the Chesapeake Manure Summit, convened July 13, 2010, in conjunction with the National Manure Expo held at Rock Springs, Pennsylvania. Contributors include Anthony Buda, Curt Dell, and Sarah Fishel from USDA ARS, University Park, Pennsylvania; Ann Swanson from Chesapeake Bay Commission, Annapolis, Maryland; Bill Satterfield from Delmarva Poultry Industry, Inc., Georgetown, Delaware; Chris Henry from University of Nebraska, Lincoln, Nebraska; Peter Wright from USDA NRCS, Syracuse, New York; Denise Coleman from USDA NRCS, Harrisburg, Pennsylvania; Bill Boyd from USDA NRCS, Greensboro, North Carolina; Norman Widman from USDA NRCS, Washington, DC; Richard Fitzgerald from USDA NRCS, Richmond, Virginia; Karl Brown and Doug Goodlander from PA State Conservation Commission, Harrisburg, Pennsylvania; Eric May, Fawzy Hashem, and Leo Kibet from University of Maryland Eastern Shore, Princess Anne, Maryland; Greg Albrecht from New York State Department of Agriculture and Markets, Ithaca, New York; Greg Binford and Dave Hansen from University of 
Delaware, Newark, Delaware; Hank Zygmunt, Ashley Toy, and Kyle J. Zieba from USEPA, Philadelphia, PA; Ross Orner from Orner Farms Inc., Rockton, Pennsylvania; Sherm Haas from Haas Farms Inc., Rebersburg, Pennsylvania; Bill Cook from Aurora Ridge Dairy, Aurora, New York; Bruce McPheron, Denise Wardrop, Matt Royer, Ross Pifer, Jay Angle, and Justin Dillon from Pennsylvania State University, University Park, Pennsylvania; George Allen and Caroline Potter from Northeast Dairy Producers Association, Syracuse, New York; Don Williams from Somerset County Conservation District, Somerset, Pennsylvania; Marel Raub from Chesapeake Bay Commission, Harrisburg, Pennsylvania; Patricia Steinhilber from University of Maryland, College Park, Maryland; Royden Powell from Maryland Department of Agriculture, Annapolis, Maryland; Russell Redding from Delaware Valley College, Doylestown, Pennsylvania;Amy Bradford and Jennifer Reed-Harry from PennAg Industries, Harrisburg, Pennsylvania; Bill Angstadt from Delaware-Maryland Agribusiness Association, Lynch, Maryland; Carl Lucero from USDA Office of Environmental Markets, Washington, DC.

Mention of trade names or commercial products in this publication is solely for the purpose of providing specific information and does not imply recommendation or endorsement by the USDA. USDA is an equal opportunity provider and employer.

\section{REFERENCES}

Blankenship, K. 2005. Solutions sought for excess manure piling up on farms. Chesapeake Bay Journal.

Chesapeake Bay Program. 2010. Nutrients. http://www.chesapeakebay.net/nutrients. aspx?menuitem=14690.

Brosch, C. 2010. Estimates of county-level nitrogen and phosphorus data for use in modeling pollutant reduction - documentation for Scenario Builder version 2.2. ftp://ftp.chesapeakebay.net/ modeling/P5Documentation/Scenario Builder Documentation - FINAL 9_16_2010.pdf.

Dou, Z., D.T. Galligan, C.F. Ramberg, Jr., C. Meadows, and J.D. Ferguson. 2001. A survey of dairy farming in Pennsylvania: Nutrient management practices and implications. Journal of Dairy Science 84:966-973.

Federal Leadership Committee for the Chesapeake Bay. 2010. Executive Order 13508-Strategy for Protecting and Restoring the Chesapeake Bay Watershed. http://executiveorder.chesapeakebay. net $/$ file.axd?file $=2010 \% 2$ F5\%2FChesapeake $+\mathrm{E}$ O+Strategy\%20.pdf.

Lima, I.M., A.A. Boateng, and K.T. Klasson. 2009. Pyrolysis of broiler manure: Char and product gas characterization. Industrial and Engineering Chemistry Research 48:1292-1297.

Parker, D. 2004. Creating markets for manure: Basin-wide management in the Chesapeake Bay Region. Presented at the Annual Meeting of the Northeast Agricultural and Resource Economics Association and the Canadian Agricultural Economics Society, Halifax, Nova Scotia, Canada, June 20-23, 2004.

Piccinini, S. and G. Bortone. 1991. The fertilizer value of agricultural manure: Simple rapid methods of assessment. Journal of Agricultural Engineering Research 49:197-208.

Ribaudo, M., N. Gollehon, M. Aillery, J. Kaplan, R. Agapoff, L. Christensen, V. Breneman, and M. Peters. 2003. Manure management for water quality: Costs of animal feeding operations of applying nutrients to land. Agricultural Economic Report 824. Washington, DC: USDA Economic Research Service.

Shortle, J. 2012. Water Quality Trading in Agriculture. Paris, France: Policies and Environment Division, Trade and Agriculture Directorate, Organization for Economic Cooperation and Development.

Stubbs, M. 2011. Environmental Regulation and Agriculture. CRS Report for Congress, Congressional Research Service, 7-5700, R41622. http://www.nationalaglawcenter.org/ assets/crs/R41622.pdf.

Tafdrup, S. 1995.Viable energy production and waste recycling from anaerobic digestion of manure and other biomass materials. Biomass and Bioenergy 9:303-314.
USDA NRCS (Natural Resource Conservation Service). 2011. Section I (General References) of the Field Office Technical Guide for Pennsylvania. http://efotg.sc.egov.usda.gov/references/public/PA/590NutrientManagement MWG_20122010_.xlsx.

USEPA (US Environmental Protection Agency). 2010. Guidance for Federal Land Management in the Chesapeake Bay Watershed. http://www. epa.gov/owow_keep/NPS/chesbay502/pdf/ chesbay_chap02.pdf. 